\title{
Modelling attitudes to nature, tourism and sustainable development in national parks: A survey of visitors in China and the UK
}

\begin{abstract}
This research undertook a visitor survey in two protected areas in different cultural contexts, namely China and the UK, to explore whether the value a person attaches to the environment influences their attitude towards sustainable tourism development in national parks. Structural equation models were developed with data from 597 and 368 questionnaires collected in Jiuzhaigou National Scenic Area, China and the New Forest National Park, UK respectively. The results suggested that anthropocentric or ecocentric values significantly influence people's attitudes to tourism and sustainable development. The same structured causal relationship was found in both samples, between people's attitudes towards the natural environment, conservation and tourism in a national park context.
\end{abstract}

Keywords: anthropocentric; ecocentric; national park; sustainable development; environmental attitudes.

\section{Introduction}

National Parks are important places for experiencing nature, including for example, nature tourism and ecotourism (Fennell \& Nowaczek, 2010). Whether the rationale for a park's designation was principally for aesthetic purposes, conservation, recreation or tourism (Frost \& Hall 2009), they are popular tourist attractions. However, the over-development of tourism in many national parks is causing serious concern about the natural environment (Eagles \& McCool, 2002; La Page 2010). Yet many park managers in the world are under increasing pressure to provide more visitor facilities and accommodation, and to provide different types of activities to meet the growing demand of visitors (Huang, Deng, Li \& Zhong, 2008). Whilst the tension between the requirements of recreation and the needs for conservation have been recognised (Barros, 2005), it is acknowledged that in some developing countries, it is the user fees and other tourism related revenues which provide the funding for conservation in the parks (Eagles, Romagosa, Buteau-Duitschaever, Havitz, Glover \& McCutcheon, 2013). As Page and Connell (2009) recognise, there is a symbiotic relationship between tourism and the environment, with each dependent on the other. More specifically, there can also be commensal relationships in which tourism benefits and the environment is unharmed or parasitic relationships in which tourism is not only exploitive of nature, but also damaging to it.

The sustainable development of tourism is now acknowledged globally (Connell, Page \& Bentley, 2009) and has become a research focus over recent decades (e.g. Clarke, 1997; Swarbrooke, 1999; Robinson, Swarbrooke, Evans, Long \& Sharpley, 2000; Liu, 2003; Gössling, Hall \& Weaver 2009). Clarke (1997, p. 224) argues that 'sustainable tourism is not an inherent characteristic of any existing form or situation, but a goal that all tourism must strive to achieve'. However, Buckley (2012, p. 534) states that mainstream tourism is still 'far from sustainable'. Any movement towards attainment is dependent not only upon the industry and other key stakeholders but also the demand side, namely the tourists (Choi \& Sirakaya 2005). Yet, there is a limited literature in this area contributing to an understanding of tourists' attitudes to tourism and sustainable development. Also, much of the research on sustainable development is based on traditional attitude theory, in which attitudes are measured on behavioural dimensions. Furthermore, studies on attitudes are often measured individually, rather than acknowledging 'the complex and multidimensional issues' (Nunkoo \& Ramkissoon, 2012, p.777) that contemporary tourism researchers contend with and accordingly this study recognises attitudes as interconnected.

The human-nature relationship is fundamental in resource management. Schroeder states (2007, p.293) that 'people's judgements about the acceptability of different kinds of human activity in natural environments often seems to stem from an underlying sense of how humans are related to non-human nature'. Schultz, Shriver, Tabanic \& Khazian (2004) suggest that there is a connection between people's attitude towards nature and their attitudes towards environmental issues. 'The degree to which an individual associates him or herself with nature is directly related to the type of attitudes that he/she develops' (p. 39). It is also argued that an individual's beliefs about nature and the human role in it are a fundamental component of a person's belief system in relation to the environment (Dunlap, Van Liere, Mertig \& Jones, 2000). Stern \& Dietz's (1994) value-basis theory suggests that there is a causal relationship between perception of the environment and the value a person 
attaches to it. Holden (2008) agrees that how the environment is perceived influences the use of the environment as a resource. Therefore, how a person perceives the environment may be consequential in their support for sustainable tourism. Thøgersen \& Olander (2002) tested a causal relationship between values and behaviour in terms of sustainable consumption and found that value priorities are causally important for sustainable consumption. Whilst their study researched normal daily consumption, it implies that a specific form of consumption, such as tourism, may be similarly influenced.

Two fundamental attitudinal perspectives in relation to the natural environment have been recognised as both contemporary and pervasive (Milfont \& Duckitt, 2004). One, an 'anthropocentric' perspective, (first identified in the 1860s) represents the idea that humans are the centre of the universe (Campbell, 1983). Anthropocentrism considers humans to be the most important life form, and other forms of life to be important only to the extent that they can be exploited (Kortenkamp \& Moore 2001; Page \& Connell 2009). In contrast, the second, ecocentrism is defined by Page \& Connell (2009, p. 641) as 'the view that nature must be preserved for its intrinsic values'. As Fennell \& Nowaczek (2010, p. 242) state: 'Ecocentrism encapsulates a naturecentred system of values'. Although often overlooked, Thompson \& Barton (1994) note that individuals of both ecocentric and anthropocentric persuasions can express positive attitudes towards environmental issues. They may be concerned about protection of the environment and support its conservation, but for different reasons (Shultz \& Zelezny, 1999). An anthropocentric person supports environmentalism in consideration of the benefits it may offer people, whilst an ecocentric person may support the same causes but their inspiration is nature centred.

Attitudes to the natural environment are consequently influential in determining how environmental resources are used (Bruun \& Kalland, 1995; Schultz, Gouveia, Cameron, Tankha, Schmuch, \& Franek, 2005; Holden, 2008) and La Page (2010) asserts that it was this that led to environmental protection and measures such as the introduction of national parks. If therefore the use of national parks and the consequent environmental issues are shaped by people's attitudes towards the environment, then a deep rooted exploration of how nature is perceived should be undertaken. Tourists' environmental attitudes have been discussed in various studies (Ryan, Hughes \& Chirgwin 2000, Weaver 2002; Choi \& Sirakay, 2005; Uriely, Reichel \& Shani 2007); however, it seems that limited research has been undertaken on how environmental attitudes translate into support for conservation and sustainable tourism development. Settings such as national parks have been shown to be useful in examining people’s pro-environmental attitudes (Ramkissoona, Smith \& Weiler, 2013). Therefore, this paper identifies a structured, causal relationship between attitudes to nature, the environment and tourism from the responses of visitors in a national park context.

Researchers suggest that attitudes develop within a normative or value-based context (Bell, Greene, Fisher \& Baum, 2001) and attitudes to the natural environment have therefore developed geographically and historically. Holden (2008 p. 26) argues that a cultural group 'often reveals distinct variations in how they view nature, supported by their spiritual and religious beliefs which influence our interaction'. It has been suggested, for example, that there may be considerable variation between the Eastern and Western perceptions of nature (Sofield \& Li 2007; Wen \& Ximing 2008). In China, a key teaching of Taoism is of the 'unity of man and Heaven', and Confucian pragmatism suggests either 'obey nature and to protect it, or to transform nature and utilise it' (Wen \& Ximing 2008, p. 573). In western cultures, such as in Britain, the traditional Judeo-Christian perspective and 'the Bible's most persistent environmental message is that God confers human dominion over nature’ (Kay 1989 p. 214).

Accordingly, this study addresses a number of gaps in the previous research. First, it establishes whether the differing attitudes to nature (anthropocentrism and ecocentrism) cause different attitudes towards sustainable development in national parks, by identifying the casual relationships between nature attitude, tourism, conservation and sustainable development. Secondly, it explores whether the framework can be applied to different cultural groups. The research therefore develops a model using responses from visitors to protected areas in both China and the UK.

The paper begins with a brief general discussion of attitudes and related psychological constructs before considering specific attitudes towards the natural environment, conservation, tourism and sustainable tourism development in national parks. Thereafter, the contexts for the research, Jiuzhaigou National Scenic Area in China and the New Forest National Park in the UK are discussed. Subsequently, the methodology which consists of structural equation modelling is described, with each step in the analysis being based on theoretical reasoning (Nunkoo \& Ramkissoon 2012). Finally the findings of the empirical research are presented with the 
aim of demonstrating whether the value a person attaches to nature influences their attitudes towards tourism and the environment, and hence to conservation and sustainable development in national parks.

\section{Conceptual development}

Attitudes are one construct amongst others, such as ethics, values, beliefs and opinions that have been used to explain behaviour. Although unobservable they can be inferred from self-reflection and self-reporting (Bell, Greene, Fisher \& Baum 2001) and are generally accepted to be an evaluation (either positive or negative) of something based on affect (emotion) and cognition. They are narrower than an ethic or value, (which are discussed next) but derived from them (Ajzen \& Fishbein, 1980; Grob, 1995) and together with beliefs and values form opinions. Therefore, environmental ethics influence environmental values which in turn influence environmental attitudes.

Environmental ethics contribute to the development of attitudes because as Burns, MacBeth \& Moore (2011) state ethics underline all decisions and actions. The development of an individual's environmental ethics is influenced by an internal change in their intellectual emphasis, loyalties, affections and convictions (Leopold, 1949). Environmental ethics are also inseparable from landscape aesthetics (Gobster, 1999) and Manning \& Valliere (1996) found that ethics were related to attitudes toward wilderness management in a study of visitors to the Broadleaf Wilderness in Vermont, USA. Subsequent research suggests that environmental ethics influences a person's environmental attitude (Light, 2002), and as a consequence they may influence the use of the environment in the tourism industry, for example, in support of wildlife tourism and ecotourism (Fennell \& Nowaczek 2010).

Environmental values are defined by Park, Jorgensen, Swanwick \& Selman (2008, p. 589) 'as individual or shared community or societal beliefs about the significance, importance and the well-being of the natural environment and how the natural world should be viewed and treated by humans'. According to Pearce and Turner (1990, p. 226-227) environmental values are the result of private and public preferences since 'individuals are assumed to operate according to their own preferences within the context of physical requirements and social norms'. An understanding of values, as a form of guiding principle in people's lives, is crucial in the formation process of environmental attitudes (Rokeach, 1973). As Bennington \& Moore (2011) observe, citizens become part of a responsible community involved in actively developing values, therefore, understanding how they view nature is important when making decisions relating to the sustainable use of nature. Stern \& Dietz's (1994) value-basis theory suggests that the value a person attaches to the environment depends on the perception of the environment and consequently influences the use of its resources (Bruun \& Kalland, 1995; Stern 2000; Schultz et al. 2005). 'A person who values economic development above other social goals may be especially likely to accept information suggesting that environmental protection will compromise economic goals' (Stern \& Dietz, 1994 p 68). Stern, Dietz, Abel, Guagnano, \& Kalof, (1999) further develop this into a Value-belief-norm theory which suggests there is a causal relationship between a person's values and the human-environmental relationship; environmental behaviour is a consequence of that result. Schultz \& Zelenzny (1999) agree and suggest an individual's values influence their environmental attitude. Bramwell \& Lane (2013, p. 2) suggest that people are 'creatures of social routine and habit' and 'their behaviours are locked into and reproduce the social practices and institutions that are the basis of social systems'. They urge that a systematic revisit of values and social practices are needed for a shift to radically more sustainable tourism.

\subsection{Attitudes towards the natural environment}

Over the centuries, people's attitudes towards nature have changed considerably. Attitudes are socially and culturally constructed, and often interrelated with many influencing factors, such as socio-demographics, religion, cultural and ethnic background, collective pressure, laws and regulations, and media coverage (Rokeach, 1973; Pearce \& Turner, 1990; Cairncross, 1991; Gössling, 2002; Duerden \& Witt, 2010). An individual's beliefs about nature and the human role in it is a fundamental component of people's belief system in relation to the environment (Dunlap et al. 2000) and there is a connectedness between people's attitude towards nature and their attitudes towards environmental issues. 'The degree to which an individual associates him or herself with nature is directly related to the type of attitudes that he/she develops' (Schultz, et al. 2004, p. 39). Page \& Dowling (2002) agree that due to different world views, people differ over the use of the resources and the degree to which environmental problems exist. Therefore, understanding how people view nature has a central role in understanding their attitude towards the environment.

Two dominant attitudes to nature, anthropocentrism and ecocentrism, have been identified as derived from environmental ethics (Thompson \& Barton, 1994). Anthropocentric people see nature as a resource to exploit; they appreciate the instrumental value that nature can offer to enhance their quality of life (Godfrey-Smith, 1979) 
and that economic growth is necessary for human development (Page \& Dowling 2002). Human beings and nature are often seen as separate as suggested by Kant and Descartes (Eckersley, 1992) and people have dominion over nature (Pointing, 1992). Researchers agree the anthropocentric perception is widespread and is considered to be responsible for several environmental crises (Gaston, 2005). It was traditionally the dominant approach in Western culture (Holden, 2008) prior to the development of modern environmentalism. Leopold (1949) recognised that a change in ethics with regard to human interaction with the natural world was needed and Hardin (1968) subsequently agreed that there should be a similar moral shift in human behaviour. These ideas developed into an ecocentric position. Ecocentrism recognises the intrinsic value of nature (Page \& Dowling 2002); nature possesses value in its own right, human beings and nature are of equal value (Wearing \& Neil 2009) and people are seen as part of nature.

This perspective was initially recognised in 1913 and was, and sometimes still is, referred to as 'biocentrism' (Kortenkamp \& Moore 2001). It was then adopted by deep ecologists in the 1970s and represents the idea that humans are part of nature and that nature possesses value in its own right (MacKinnon, 2007). Ecocentrism acknowledges that humans should have their simple material needs met (Page \& Dowling 2002) and recognises that some forms of economic growth are beneficial for the environment but maintains that others are harmful (Yeoman, 2000). Some authors also recognise a spiritual value in the natural environment (Curtin, 2005; Winter, 2007) conceptualised as a deep ecology view (Wapner \& Matthew 2009).

Researchers (Thompson\& Barton, 1994; Shultz \& Zelezny, 1999) found that irrespective of whether an individual is of an ecocentric or anthropocentric persuasion they can nonetheless express positive attitudes towards environmental issues. However, they differ, in that anthropocentrism supports environmentalism in consideration of the benefits it may offer people, whilst ecocentrism may support the same causes but their inspiration is nature centred. In this view, an anthropocentric person might be against damaging a rainforest for its potential resource for timber, recreation and tourism; whilst an ecocentric person might be opposed to it because of their belief that human beings and nature are in harmony. Research on the difference between the two attitudes has been carried out by environmental psychologists. For example, Dunlap \& Van Liere (1978) first incorporated the concept into their New Environmental Paradigm scale to measure pro-environmental attitude. This therefore recognised the ecological interdependence of people and nature and hence rejected social determinism. It also demonstrated that the two different conceptualisations could influence different proenvironmental behaviour.

\subsection{Attitudes to conservation and sustainable development in parks}

Conservation is described by Brockington, Duffy \& Igoe (2008, p. 6) as an 'incredibly broad church and one that is riven with conflict'. It 'implies a unity of thought, values and practice that is simply not found'. Accordingly, attitudes to conservation are therefore equally diverse. Nonetheless, conservation and sustainability are both associated with ecocentrism (Page \& Dowling, 2002).

This concern for the environment and conservation can be found in the rapidly increasing numbers of protected areas worldwide, for example the boom in the growth of national parks. The world's first national park, Yellowstone, was established in 1872. Nature has always played an important role, in what Nash (1970, p. 266) called an 'American invention', arising from the US's 'unique experience with nature in general and wilderness in particular'. As the concept of national parks spread, it evolved to adapt to the various physical, political and social environments locally. For example, in England, national parks have a strong recreational focus and with many private land owners maintaining a living inside the parks, they are sometimes referred to as a 'living landscape' (Eagles \& McCool, 2002). A national park system was first created in England in the 1950s, recognising the need for environmental conservation and providing access to the countryside (Thompson, 2005). The development of national parks worldwide can be broadly divided into four stages as summarised in Table 1 . This global history of national parks suggests that initially, an anthropocentric perception of nature prevailed as reflected in the USA and New Zealand whilst later, a more scientific focus with greater concern for the ecology and indigenous species developed (Frost \& Hall, 2009), reflecting a more ecocentric perception of national parks. However, a focus on the local community and regional development are also now important dimensions of park development. Finally, as Mose \& Weixlbaumer (2007) argue, parks are now facing a new shift of paradigm demonstrating a sharper scientific focus and limiting human activities to a higher degree, and a more integrated management model is therefore needed.

\section{Insert Table 1 here.}

Previous attitudinal research with tourists in national parks has considered their support for management actions in Yellowstone National Park, amongst winter visitors (Borrie, Freimund, \& Davenport, 2002); foreign tourists' requirements for facilities in Norwegian national parks (Haukeland, Grue \& Veisten, 2010) and 
attitudes towards the management of visitors to the Gesaeuse National Park, Austria (Arnberger, Eder, Allex, Steri \& Burns, 2012). Attitudes towards conservation have been studied in Yellowstone National Park regarding wolf recovery (Duffield, Neher \& Patterson, 2008) and attitudes to bark beetle infestation in a German national park (Müller \& Job, 2009). Studies on interrelated attitudes are rarer, but Martín-López, Montes \& Benayas (2007) considered biodiversity and its economic value in the Doñana National and Natural Park, Spain.

\subsection{Attitudes towards tourism and the environment}

There has developed a considerable literature on the environment-tourism relationship (Holden, 2008; Sharpley, 2009). Tourism development can be influenced by environmental attitudes from both the demand and the supply side, revealed by the shift from mass tourism to sustainable tourism, ecotourism, and green tourism. From each, there are examples of tourists and suppliers on a continuum from those who are unthinking or uncaring to the 'green' and supporters of ecotourism, ranging from low to high environmental commitment.

There have been several studies measuring the level of environment concern of tourists (Milfont \& Duckitt, 2010). Wurzinger \& Johansson's study (2006) for example, among three groups of Swedish tourists, suggests that ecotourists express more general environmental beliefs than nature tourists, who, in turn, have more proenvironmental beliefs than city tourists. Even within ecotourism, there are variations. A revised New Environmental Paradigm has been used to classify different types of ecotourists between 'hard-path' and 'softpath' ecotourists (Fennell, 2007), or 'deep’ and 'shallow' ecotourists (Acott \& La Trobe, 1998). Each group has different environmental concerns, for example, the hard ecotourists are those who spend a significant time in the field in less than ideal conditions, whilst the soft ecotourists are usually looking for general, casual experiences with more desire for a comfortable stay. Therefore each group has different requirements in terms of tourism facilities and activities. In a recent study on wildlife tourism, Burns et al. (2011) found that ecocentric values influence wildlife tourism management, with positive outcomes for both people and wildlife, through the recognition of the intrinsic value of wildlife and the moral reasoning behind a wildlife tourism experience.

Whilst research on ecotourism and wildlife tourism suggests that people’s environmental attitudes differ, whether and how these views might influence their support for sustainable tourism is unclear. Much attention has been given to sustainable tourism as an alternative form of tourism in national parks (Landorf, 2009). For example, Boyd (2000) lists a range of activities which take place inside parks, including wildlife protection, conservation, tourism, research and interpretation. Huang et al. (2008) undertook a study of sustainable activities in parks, seeking to define different types of activities according to their level of sustainability. Passive activities (for example, watching wildlife, photography and hiking) are viewed as appropriate. Moderately appropriate use is associated with some consumptive activities, such as fishing and gathering natural edible products, picnicking, and non-motorised activities. Motorised, urban related and resource consumptive activities are viewed as inappropriate in parks. The different responsibilities in national parks worldwide suggest a local, social-cultural dimension cannot be ignored. As Ma, Ryan \& Bao (2009) suggest, in China the concept of wilderness hardly exists in the Chinese literature, and there is a high degree of urbanisation within park boundaries to cater for the demand for accommodation and accessibility as well as the enhancement of nature by manmade artefacts. While in Canada, parks always contain large areas of wilderness with only very limited tourism and recreational use (Frost \& Hall, 2009). The reason for these differences are explained by Shultz et al. (2004) in that people from different cultures may have different environmental attitudes, hence the variation in the use of environmental resources.

From this review of the literature the following hypotheses were created:

Hypothesis 1. An anthropocentric attitude has a significant and positive influence on tourism and the environment.

Hypothesis 2. An ecocentric attitude has a significant and negative influence on tourism and the environment.

Hypothesis 3. People's attitudes to tourism and the environment significantly influence their attitudes to conservation in national parks.

Hypothesis 4. People's attitudes to tourism and the environment significantly influence their attitudes to sustainable tourism in national parks.

Hypothesis 5: An anthropocentric attitude significantly influences people's attitude to conservation in national parks. 
Hypothesis 6: An ecocentric attitude significantly influences people’s attitude to conservation in national parks.

Hypothesis 7: An anthropocentric attitude significantly influences people's attitude to sustainable tourism in national parks.

Hypothesis 8: An ecocentric attitude significantly influence people's attitude to sustainable tourism in national parks.

From the above discussion of the literature, a theoretical model was developed (Figure 1).

Insert Figure 1 here

\section{Methodology}

This paper is part of a research project, comparing visitors to two protected areas, one in England and the other in China, and which therefore have different social, economic and cultural contexts. Surveys were undertaken in the New Forest National Park, in southern England and Jiuzhaigou National Scenic Area in China. The New Forest is the largest lowland heath in Europe, and the Park attracts about 3 million visitors a year (New Forest District Council, 2012). Jiuzhaigou is a World Nature Heritage site, which attracts 2.6 million tourists a year (Cheng, Xu \& Zhang, 2009). Both parks are popular nature tourism destinations. Detailed information about the two parks can be found in Table 2.

Insert Table 2 here.

\subsection{Measures}

The same questions were used in each survey. The first part of the questionnaire contained questions about visitors' frequency of visiting the protected area and their motivation for doing so. (These results will be presented in other papers.) This paper considers the second and third parts of the questionnaire, which included questions on sustainable development and the human-nature relationship. In respect of the former, Boyd's (2000) measurement of sustainability of activities in national parks was adopted. Two items were conservation based (nature/scenery conservation and wildlife conservation) and four related to sustainable tourism development (education/interpretation, leisure and tourism, scientific research, local community development). To assess anthropocentric and ecocentric views of nature, eight items were developed based on Thompson \& Barton, (1994) and Page \& Dowling (2002). Finally, two statements were produced, positioned on the work of Stern \&Dietz (1994), highlighting the value and hence priority of tourism over the environment. Rating for each statement was based on a Likert scale ranging from (1) strongly agrees to (5) strongly disagrees. The questionnaire also included closed questions on demographic variables, such as gender, age and nationality. The questions were designed in English and then translated into Chinese. A back translation (Werner \& Campbell, 1973) was used to ensure the clarity of translation.

\subsection{Sampling method and data collection}

A pilot test was conducted on a convenience sample of 20 university students (10 in China and 10 in England) to clarify the wording. Based on the feedback, a few statements were reworded to improve understanding of the question. The finalised version of the questionnaire included an introductory note as to the nature of the research. Convenience samples were used, with 600 printed questionnaires distributed in each park in May, 2008. The questionnaires were administered using a direct face to face survey method because of the relatively high response rate of this method (Lee, 2013). In China, 597 completed and useable questionnaires were collected and in England, 368.

\subsection{Data analysis}

The data were analysed using SPSS 20 and AMOS 20. An Exploratory Factor Analysis (EFA) was used first with the pooled data to identify small subsets of potentially optimal indicator variables for each hypothesised latent variable. The Cronbach's alpha scores for the latent variables varied from 0.717 to 0.831 , all of the scores exceeded the benchmark of 0.70 (Nunnally \& Bernstein, 1994), suggesting a good level of internal consistency of the factor analysis (Hair, Anderson, Tatham, \& Black, 2002). For the subsequent Confirmatory Factor Analysis (CFA) and Structural Equation Model (SEM) analyses (and strictly, for the preceding EFA,) manifest variables should be measured on interval scales and show univariate and multivariate normality. In this study discrete ordinal scales were used, which do not meet the continuity assumption strictly required. Although 
it is unrealistic to expect such scales to be normally distributed, an assessment of univariate and multivariate normality was made, and the possibility of outliers was examined (Byrne, 2009). Univariate normality was fairly satisfactory (maximum observed Kurtosis $=4.4$ ). No observations with 'outstandingly large' outliers Mahalanobis $\mathrm{D}^{2}$ were present. Departure from multivariate normality was present (Multivariate Kurtosis $=71.9$, $\mathrm{CR}=46.6$, and least 100 cases were at distances inconsistent with the assumption of multivariate normality (p2 $<0.001)$ ). Despite the potential risk posed by these assumption violations, Maximum Likelihood (ML) estimation was used, but bootstrap ML estimates and Bayesian estimates were calculated to assess the extent to which non-normality and discrete ordinality may have influenced the ML estimates. Generally this approach suggests that ML estimates are sufficiently reliable to sustain the inferences made in subsequent analyses.

Then CFA was employed to test whether the underlying structure could form a tenable measurement model for the constructs, with modifications and adjustments when necessary (Huang \& Hsu, 2009). Commonly recommended indices were used to measure model fitness, goodness-of-fit statistic $\left(\chi^{2}\right)$, comparative fit index (CFI) and root mean square error of approximation (RMSEA) (Hosany \& Witham, 2010). The ratio of $\chi 2 / \mathrm{df}$ has been recommended as a better goodness of fit than $\chi 2$ (Chen \& Tsai, 2007). As this study has a large sample size ( $\mathrm{n}=965)$, it can affect the value of $\chi 2$ (McDonald \& Ho, 2002), therefore, $\chi 2 / \mathrm{df}$ ratio is used. A threshold of less than 3 for a serious view point or less than 5 for acceptable criteria is suggested (Lee, 2013). In this study, the sample size of 965 seems to be adequate for performing the SEM analysis on the basis of Hoelter's statistic at $\mathrm{p}=0.01(413)$ and the ratio of sample size to indicators (60) and sample size to estimated parameters (16) (Westland, 2010).

\section{Results}

\subsection{Respondent profile}

Both samples are similar in respect of gender and age, differing only in their travel patterns to the protected areas. The Chinese sample was 59.6\% male, mainly between 26-45 years old (61.1\%) and travelling with a package tour (69.3\%). The British sample was 60.3\% male, mainly between 36-55 years old (50.1\%) and visiting independently (98.2\%).

\subsection{Measurement model}

The CFA hypothesises some latent variables as 'causes' of observed responses. It then allows measurement and assessment of the validity of these latent variables (Byrne, 2009). As the initial CFA failed to provide an acceptable fit, one item (natural medicines are more effective than man-made medicines) was eliminated to obtain an acceptable model. The results of the CFA had been improved, the chi-square $\left(\chi^{2}\right)$ value of the model was 300.748, with 94 degrees of freedom $(\mathrm{p}<0.05)$. The $\chi^{2} / \mathrm{df}$ ratio of the model in this case is 3.19 , indicating an acceptable fit (Hair et al., 2002; Lam and Hsu, 2006; Sparks, 2007; Huang and Hsu, 2009; Byrne, 2009).

Table 3 lists the factor loadings, and as they all exceeded 0.5, this suggests the measurement reached convergent validity at the item level. Table 4 lists the Average Variance Extracted (AVE), and the Construct Reliability (CR). Suggested by Bacon, Sauer \& Young (1995), construct reliability does not assume classical tau-equivalence compared with composite reliability, therefore, construct reliability is used in this study. All of the construct reliability values exceeded 0.7, suggesting a high level of internal consistency for the latent variables. The squared correlations between pairs of constructs were less than AVE estimates of either of the two constructs with exception of one latent (See Table 4), suggesting discriminant validity.

Insert Table 3 here.

Insert Table 4 here.

\subsection{Structural model}

The measurement model was then turned into a configural structural model according to the theoretical model, after initially checking its satisfactory fit on the pooled samples. All parameters shown were significant, apart from Tourism \& the environment -> Conservation and Tourism \& the environment -> Sustainable tourism. These non-significant regression weights were not deleted at this point. The fit of this model was not significantly different from that of the measurement model.

The configural structural model was then fitted simultaneously to both groups (Chinese \& British). Figure 2 shows the unstandardised parameter estimates for the British sample, and overall goodness of fit measures. All parameter estimates in at least one group are significant. [Covariance matrices, standardised residual covariance 
matrices, estimates, critical ratios and probabilities for the British and Chinese samples, and other GOF measures relating to this model are given in the Appendices A,B,C and D.]

Insert Figure 2 here.

It is notable that the regression paths Anthropocentric -> Sustainable tourism, Ecocentric -> Sustainable tourism and Tourism \& environment -> Sustainable tourism have been deleted, as neither was significant in either group. This results in a slightly less well fitting model, but the improvement in parsimony is considered to justify this (See Table 5).

Insert Table 5 here.

As in the case of all models considered, the effect of assumption violations was assessed by comparison of the ML estimates, bootstrap ML estimates, and Bayesian estimates. A typical comparison of measurement regression weights for the British and Chinese samples is illustrated for this model in Appendix E.

\subsection{Between-groups structural comparison}

Structural invariance between British and Chinese samples was then evaluated with a nested series of models in which, at the first level, measurement weights were constrained equally across groups, and the $\Delta \chi^{2}$ between the initially unconstrained model (Model 1 in Table 6) and the constrained model (Model 2) was tested and the $\Delta \chi^{2}$ was found to be significant. The measurement weight with the largest between-groups difference was identified (Cons->Y4), this was freed and the resulting model (Model 3) compared with the unconstrained (Model 1). This time, a non-significant $\Delta \chi^{2}$ was obtained. Structural weights were then constrained equally (Model 4), and the resulting model compared with the model having partially constrained measurement weights (Model 3). Again, a non-significant $\Delta \chi^{2}$ was obtained.

Insert Table 6 here.

The model is invariant between the British and Chinese groups in measurement and structural weights with the exception of Conservation -> Y4 (wildlife conservation should be carried out in national parks), for which the unstandardised ML estimates are: British = 1.05, SE = .086; Chinese $=0.76, \mathrm{SE}=.050$; One thousand bootstrap ML estimates suggest this difference is substantive: British $=1.053$, SE $=.097$ (95\% bias corrected confidence limits: $0.893: 1.205)$; Chinese $=0.760, \mathrm{SE}=.063$ (95\% bias corrected confidence limits: 0.655 : $0.861)$

Whilst there is academic interest in the agreement between ML, bootstrap and Bayesian estimates confirming the reality of this difference, substantively, the difference is trivial, and it is more reasonable to conclude that no difference has been found between the structural model estimated for the British and Chinese samples.

\section{Discussion}

From the review of the literature, it is assumed that attitudes to nature might influence people's attitudes to tourism and the environment. From the results presented above, it shows that:

H1 Anthropocentric values have a significant, positive influence on respondents' attitudes to tourism and the environment.

This is found in the model, confirmed by both groups. It suggests that visitors, who score highly on the anthropocentric questions, also score high on the tourism and environment questions. That is, people who are anthropocentric believe that tourism's economic benefits are more important than the environmental benefits of nature.

H2 Ecocentric values have a significant, negative influence on respondents' attitudes to tourism and the environment.

This is again confirmed. Therefore those who are ecocentric disagree that tourism's economic benefits are more important than the environmental benefits of nature. They also disagree that the economic benefits of tourism are more important than the economic benefits of nature. 
H1 and H2 were accepted, showing people's attitude to nature significantly influences their attitudes to tourism and the environment, with anthropocentric and ecocentric respondents each having a different attitude to tourism and the environment. Therefore, an attitude to nature can be used to predict attitudes towards tourism and environment. This finding supports previous research (Wurzinger \& Johansson, 2006; Milfont \& Duckitt, 2010; Burns et al., 2011).

H3: People's attitudes to tourism and the environment, significantly influences their attitudes to conservation in national parks.

H3 was accepted, as the results of this research suggest that a respondent's attitude to tourism and the environment has a significant direct influence on conservation. In both samples, people's attitude towards tourism and the environment has a negative influence on conservation activities in parks. In other words, visitors who agree tourism is more important than the environment will disagree with conservation activities inside parks.

H4: People's attitudes to tourism and the environment, significantly influences their attitudes to sustainable tourism in national parks.

H4 was partially accepted as the attitudes to tourism and the environment does not have a direct significant influence on sustainable tourism. In other words, the respondents' attitudes towards tourism and the environment does not have a direct influence on sustainable tourism in parks, rather people's attitude towards sustainable tourism is directly, significantly positively influenced by attitudes to conservation, meaning people who support conservation would support sustainable tourism as well.

H5: An anthropocentric attitude significantly influences people’s attitude to conservation in national parks.

H6: An ecocentric attitude significantly influence people’s attitude to conservation in national parks.

These hypotheses were both accepted as an anthropocentric attitude negatively, significantly influences attitudes to conservation; while an ecocentric attitude positively, significantly influences attitude to conservation. The research suggests that people's attitude towards nature can be used to predict different attitude towards conservation, supporting the research by Schultz et al.(2004) that attitudes towards nature influences attitudes towards environmental issues.

H7: An anthropocentric attitude significantly influences people's attitude to sustainable tourism in national parks.

H8: An ecocentric attitude significantly influences people's attitude to sustainable tourism in national parks.

These were both partially accepted as the results suggest anthropocentric or ecocentric views do not have a direct significant influence on attitudes towards sustainable development in parks, but they both have an indirect significant influence on the attitudes towards sustainable tourism via conservation, although ecocentric plays a positive role, while anthropocentric plays a negative role. This confirms that those visitors who are ecocentric are more likely to support conservation activities in national parks, therefore support sustainable tourism. The result supports Stern \& Dietz's (1994) value basis theory that people's attitude towards nature influences their attitude towards the use of its resources. This research also suggests that people's attitude towards nature can be used to predict their attitude towards sustainable tourism in national park context.

In both the Chinese and British groups, ecocentrism does not have a significant direct influence on sustainable tourism; rather it has an indirect positive influence via conservation, which suggests conservation is an important factor. In return, people's attitude to conservation is significantly influenced by their attitude towards nature, with anthropocentrism playing a negative role, but ecocentrism playing a positive role.

Table 7 provides a summary of the outcomes for the hypotheses.

Insert Table 7 here.

\section{Conclusions, implications, limitations and suggestions for future research}

This study offers a number of important contributions. Most research on tourism and sustainable development is based on traditional attitude theory, in which attitudes are measured on behavioural dimensions. This research takes a further step by examining the complex structured relationship between people's attitude 
towards nature and their attitude towards tourism and activities in national parks. It makes important theoretical contributions in the following ways.

Through a rigorous examination, it suggests that there is a strong causal relationship between people's attitude towards nature and their attitude towards tourism and associated activities, providing empirical data in support of Stern \& Dietz's (1994) value based theory that people's attitude towards nature influences their attitude towards the use of a resource. Hence in respect of tourism, people's attitude of sustainable tourism development is deeply and significantly influenced by how they view nature. At a psychological level, the way in which a person views nature is related to the type of attitudes that they develop towards the use of nature. In essence, individuals who view nature in an anthropocentric way give greater priority to tourism development and the use of natural resources than to the environment. Whilst an individual who views nature in an ecocentric way gives primacy to the environment rather than tourism development. This is reflected in their support for conservation activities in parks and significantly more support for sustainable tourism than anthropocentrics. Therefore, this research has also confirmed that individuals' attitudes to sustainable tourism are similarly influenced and shaped by how they view nature. As suggested by Nash (1989) the human/nature relationship is crucial for the future development of human society. The development of an individual's environmental ethics is influenced by an internal change in their intellectual emphasis, loyalties, affections and convictions (Leopold, 1949). Some people may have made those transformations, others may not, which might explain why sometimes environmental policy fails to change an individual's behaviour because it has not changed their ethical outlook.

This research suggests that as people's attitude to nature can be used to predict attitudes towards the relationship between tourism and environment, supporting Schultz et al.'s (2004) work. To a broader extent, this research identifies how the use of nature in tourism is deeply influenced by environmental ethics; that is how people's relationship with nature is viewed. It further proves that people's attitude towards sustainable development in a national park context is significantly influenced by their environmental attitudes which is constructed socially, thus supporting Bramwell \& Lane's (2013) suggestion of revisiting of values and social practices in order to be more sustainable. Nevertheless, in order to achieve sustainable development of tourism, destination managers and stakeholders need to have an on-going awareness of the balance between people and nature.

In addition to developing a structured model of attitudes, this research has important implications for the management of national parks and other areas of conservation value. The research found people's attitude to conservation have a mediating effect between attitudes towards nature and support for sustainable tourism. Therefore, managers should concentrate on people's conservation attitudes, such as developing and promoting nature and wildlife conservation activities in parks. Secondly, as people's attitudes towards nature is important in influencing people's attitude towards sustainable tourism, park managers should ensure that ecocentric views are encouraged and heard, such as promoting a nature centred view, evoking the intrinsic value of nature, and encouraging a more ecocentric moral shift in human behaviour. Ecocentric related tourism activities, such as ecotourism and wildlife tourism could be encouraged in parks. Finally, this research confirms the relevance of a cross-cultural perspective in understanding sustainable tourism in national parks.

Like most studies, this one had limitations. First, the samples for this research consisted of respondents visiting the New Forest National Park in England and the Jiuzhaigou National Scenic Area in China. The very act of choosing to visit a national park demonstrates a particular view of natural places that may not be prevalent in the population of a country as a whole. Secondly, other influences might also sway a person's attitudes and support for sustainable tourism, including, for example, age, gender and socialisation. Future research could investigate and compare the importance of these other factors in shaping attitudes and could expand the research into other national parks both within the UK and China and/or into other countries, or whole populations, in order to build an understanding of the similarities and differences. Furthermore, different aspects within a national culture could be investigated. Last but not least, this research only examined a structured relationship among certain variables, but as attitudes are socially and culturally constructed, other factors, such as religion could be explored in the future. 


\section{References:}

Acott, T.G. \& La Trobe, H. L. (1998). An evaluation of deep ecotourism and shallow ecotourism. Journal of Sustainable Tourism. 6(3), 238-253.

Ajzen, I. \& Fishbein, M. (1980). Understanding attitudes and predicting social behaviour. Englewood Cliffs, USA: Prentice-Hall.

Arnberger, A., Eder, R., Allex, B., Steri, P. \& Burns, R.C. (2012). Relationships between national-park affinity and attitudes towards protected area management of visitors to the Gesaeuse National Park, Austria. Forest Policy and Economics, 19, 48-55.

Bacon, D.R., Sauer, P.L. \& Young, M. (1995). Composite reliability in structural equation modelling. Educational and Psychological Measurement, 55, 394-406.

Barros, C. P. (2005). Evaluating the efficiency of a small hotel chain with a Malmquist productivity index. International Journal of Tourism Research, 7(3), 173-184.

Bell, P.A., Greene, T.C., Fisher, J.D. \& Baum, A. (2001). Environmental psychology, $5^{\text {th }}$ ed. Orlando, FL: Harcourt College Publishers.

Bennington, J. and Moore, M. H. (2011) Public value in complex and changing times. In J. Bennington and M.H. Moore (Eds.) Public value, theory and practice. (pp. 1-30). Hampshire: Palgrave Macmillan.

Borrie, T., Freimund, W.A., \& Davenport, M.A. (2002). Winter visitors to Yellowstone National Park, their value orientations and support for management actions. Human Ecology Review, 9(2), 41-48.

Boyd, S. (2000). Tourism, national parks and sustainability. In R. Butler \& S. Boyd (Eds.) Tourism and national parks: issues and implications. (pp. 161-186).West Sussex: John Wiley \& Sons, Ltd.

Bramwell, B. and Lane, B. (2013). Getting from here to there: systems change, behavioural change and sustainable tourism. Journal of Sustainable Tourism. 21(1), 1-4.

Brockington, D., Duffy, R. \& Igoe, J. (2008). Nature unbound: Conservation, capitalism and the future of protected areas. London: Earthscan.

Bruun, O. and Kalland, A. (1995). Asian perceptions of nature: a critical approach. Richmond: Curzon Press.

Buckley, R. (2012) Sustainable Tourism: research and reality. Annals of Tourism Research. 39(2): 528-546

Burns, G.L., MacBeth, J. \& Moore, S. (2011). Should dingoes die? Principles for engaging eccentric ethics in wildlife tourism management. Journal of Ecotourism. 10(3), 179-196.

Byrne, B.M. (2009). Structural equation modelling with AMOS: basic concepts, applications and programming. $2^{\text {nd }}$ ed. London: Routledge.

Cairncross, F. (1991). Costing the Earth. London: Business Books.

Campbell, E. K. (1983). Beyond Anthropocentrism. Journal of the History and Behavioral Science, 19, 54-67.

Chen, C. \& Tsai, D. (2007). How destination image and evaluative factors affect behaviour intentions. Tourism Management , 28 (4),1115-1122.

Cheng, S., Xu, F. \& Zhang, J. (2009). Comparison of natural tourism planning administration modes between Chinese famous scenic sites and British national parks—-taking Chinese Jiuzhaigou scenic sites and British New Forest national park as examples. Chinese Landscape Architecture, 7, 43-48.

Choi, H.C., \& Sirakaya, E. (2005). Measuring Residents’ Attitude toward Sustainable Tourism: Development of Sustainable Tourism Attitude Scale. Journal of Travel Research, 43, 380-394. 
Clarke, J. (1997). A framework of approaches to sustainable tourism. Journal of sustainable tourism, 5 (3), 224 233.

Connell, J., Page, S., \& Bentley, T. (2009). Towards sustainable tourism planning in New Zealand: Monitoring local government planning under the resource management act. Tourism Management. 30, 867-877.

Curtin, S. (2005). Nature, wild animals and tourism: an experiential view. Journal of Ecotourism. 4(1), 1-15.

Duerden, M.D. \& Witt, P.A. (2010). The impact of direct and indirect experiences on the development of environmental knowledge, attitudes, and behaviour. Journal of Environmental Psychology, 30(4), 379-392.

Duffield, J.W., Neher, C.J. \& Patterson, D.A. (2008). Wolf recovery in Yellowstone: Park visitor attitudes, expenditures, and economic impacts. Yellowstone Science, 25 (1), 13-19.

Dunlap, R.E. and Van Liere, K.D. (1978). The New Environmental Paradigm: a proposed measuring instrument and preliminary results. Journal of Environmental Education. 9, 10-19.

Dunlap, R. E., Van Liere, K.D., Mertig, A.G. \& Jones, R.E. (2000). Measuring Endorsement of the New Ecological Paradigm: a revised NEP scale. Journal of Social Issues. 56(3), 425-442.

Eagles, P.F.J. \& McCool, S. (2002). Tourism in national parks and protected areas: planning and management. Wallingford: CABI.

Eagles, P.F. J., Romagosa, F., Buteau-Duitschaever, W.C., Havitz, M., Glover, T.D., \& McCutcheon, B. (2013). Good governance in protected areas: an evaluation of stakeholders' perceptions in British Columbia and Ontario Provincial Parks. Journal of Sustainable Tourism, 21(1), 60-79.

Eckersley, R. (1992). Environmentalism and political theory: Towards an ecocentric approach. London: UCL Press Ltd.

Fennell, D. (2007). Ecotourism. $3^{\text {rd }}$ ed. Oxon: Routledge.

Fennel D.A. \& Nowaczek, P. (2010). Moral and empirical dimensions of human-animal interactions in ecotourism: deepening an otherwise shallow pool of debate. Journal of Ecotourism, 9(3), 239-255.

Frost, W. \& Hall, C. M. (2009). American invention to international concept: the spread and evolution of national parks. In W. Frost, \& C. M. Hall, (Eds.), National parks and tourism: international perspectives on development, histories and change. (pp. 30-44) London: Routledge.

Gaston, K.J. (2005). Biodiversity and extinction: Species and people. Progress in Physical Geography, 29 (2), 239-247.

Gobster, P.H. (1999). An ecological aesthetic for landscape management. Landscape journal, 18 (1), 54-64.

Godfrey-Smith, W. (1979). The value of wildness. Environmental Ethics 1(4), 309-319.

Gössling, S. (2002). Human-environmental relations with tourism. Annals of Tourism Research. 29(2), 539-556.

Gössling, S., Hall, C.M. \& Weaver, D.B. (2009). Sustainable Tourism Futures: Perspectives on Systems, Restructuring and Innovations. In S. Gössling, C.M. Hall, \& D.B. Weaver, (Eds.) Sustainable Tourism Futures: Perspectives on systems, restructuring and innovations. (pp. 1-19) London: Routledge.

Grob, A. (1995). A structural model of environmental attitudes and behaviour. Journal of Environmental Psychology, 15(3), 209-220.

Hair, J.F.J., Anderson, R.E., Tatham, R.L., and Black, W.C. (2002). Multivariate data analysis with readings. $6^{\text {th }}$ ed. Englewood Cliffs, NJ: Prentice-Hall. 
Hardin, G. (1968). The tragedy of the commons. Science 162, 1243-1248.

Haukeland, J.V., Grue, B. \& Veisten, K. (2010). Turning National Parks into Tourist Attractions: Nature Orientation and Quest for Facilities. Scandinavian Journal of Hospitality and Tourism, 10 (3), 248-271.

Holden, A. (2008). Environment and tourism. $2^{\text {nd }}$ ed. London: Routledge

Hosany, S. and Witham, M. (2010). Dimensions of cruisers' experiences, satisfaction and intention to recommend. Journal of Travel Research. 49(3), 351-364.

Huang, S., and Hsu, C. H. C. (2009). Effects of travel motivation, past experience, perceived constraint, and attitude on revisit intention. Journal of Travel Research, 48(1), 29-44.

Huang, Y., Deng, J., Li, J., Zhong, Y. (2008). Visitor's attitudes towards China’s national park policy, roles and functions and appropriate use. Journal of Sustainable Tourism 16(1): 63-84

Kay, J. (1989). Human dominion over nature in the Hebrew Bible. Annals of the Association of American Geographers 79(2), 214-232.

Kortenkamp, K.V. \& Moore, C.F. (2001). Ecocentrism and anthropocentrism: moral reasoning about ecological commons dilemmas. Journal of Environmental Psychology 21, 261- 272.

La Page W. (2010). Rethinking park protection: treading the uncommon ground of environmental beliefs Wallingford: CABI.

Lam, T. and Hsu, C.H.C. (2006). Predicting behavioural intention of choosing a travel destination. Tourism Management. 27 (4), 589-599.

Landorf, C. (2009). Managing for sustainable tourism: a review of six cultural world heritage sites. Journal of Sustainable Tourism. 17(1): 53-70.

Lee, T. H. (2013). Influence analysis of community resident support for sustainable tourism development. Tourism Management. 34, 37-46

Leopold, A. (1949). A sad country almanac. New York: Oxford University Press.

Light, A. (2002) Contemporary environmental ethics from metaethics to public philosophy. Metaphilosophy. 33(4), 426-449.

Liu, Z. (2003). Sustainable tourism development: A critique. Journal of Sustainable Tourism. 11 (6), 459-475.

Ma, X., Ryan, C. and Bao, J. (2009). Chinese national parks: differences, resource use and tourism product portfolios. Tourism Management. 30 (1), 21-30.

MacKinnon, B. (2007). Ethics: Theory and Contemporary Issues, $5^{\text {th }}$ ed, Belmont, California: Thomson/Wadsworth.

Manning, R.E. and Valliere, W.A. (1996). Environmental values, environmental ethics, and wilderness management: An empirical study. International journal of wilderness, 2 (2), 27-32.

Martín-López, B., Montes, C. \& Benayas, J. (2007). The non-economic motives behind the willingness to pay for biodiversity conservation. Biological conservation, 139, 67-82.

McDonald, R.P. and Ho., M.H.R. (2002). Principles and Practice in Reporting Statistical Equation Analyses. Psychological Methods, 7 (1), 64-82.

Milfont, T.L. and Duckitt, J. (2010). The environmental attitudes inventory: a valid and reliable measure to assess the structure of environmental attitudes. Journal of Environmental Psychology. 30, 80-94. 
Mose, I. \& Weixlbaumer, N. (2007). A new paradigm for protected areas in Europe? In I. Mose (Ed.), Protected Areas and Regional Development in Europe: Towards a New Model for the 21st Century. (pp. 3-21). Aldershot, UK: Ashgate Publishing Limited.

Müller, M. \& Job, H. (2009). Managing natural disturbance in protected areas: Tourists' attitude towards the bark beetle in a German national park. Biological conservation, 142, 375-383.

Nash, R. (1970). The state of environmental history. In H.J. Bass (Ed.), The State of American History (pp 249260). Chicago: Organization of American Historians and Quadrangle books.

Nash, R. (1989). The rights of nature: a history of environmental ethics. Madison, Wisconsin; The University of Wisconsin Press.

New Forest District Council. (2012). Tourism and travel. Available from: http://www.newforest.gov.uk/index.cfm?articleid=5197 [Accessed 17 July, 2012].

Nunkoo, R. and Ramkissoon, H. (2012). Structural equation modelling and regression analysis in tourism research. Current Issues in Tourism, 15 (8), 777-802.

Nunnally, J. C., \& Bernstein, I. H. (1994). Psychometric theory. New York: McGraw-Hill.

Page, S.J. \& Connell, J. (2009). Tourism: a modern synthesis. $3^{\text {rd }}$ ed. Andover: South-Western Cengage Learning.

Page, S. and Dowling, R.K. (2002). Ecotourism. Harlow: Prentice Hall.

Park, J.J., Jorgensen, A., Swanwick, C. and Selman, P. (2008). Relationships between environmental values and the acceptability of mobile telecommunications development in protected areas. Landscape research, 33 (5), 587-604.

Pearce, D. W. and Turner, R.K. (1990). Economics of Natural Resources and the Environment. London: Harvester Wheatsheaf.

Pointing, C. (1992). A green history of the world. London: Penguin.

Ramkissoon , H., Smith, L.D.G. \& Weiler, B. (2013). Relationships between place attachment, place satisfaction and pro-environmental behaviour in an Australian national park, Journal of Sustainable Tourism, 21 (3), 434457.

Ryan, C., Hughes, K. and Chirgwin, S. (2000) The gaze, spectacle and ecotourism. Annals of Tourism Research, 27 (1), 148-163.

Robinson, M., Swarbrooke, J., Evans, N., Long, P. and Sharpley, R. (2000). Environmental management and pathways to sustainable tourism: Reflections on international tourism. Sunderland: Business Education Publishers Ltd.

Rokeach, M. (1973). The Nature of Human Value. New York: Free Press.

Sharpley, R. (2009). Tourism development and the environment: beyond sustainability? London: Earthscan.

Schulzt, P., and Zelezny, L. (1999). Values as predictors of environmental attitudes: evidences from consistency across 14 countries. Journal of Environmental Psychology, 19(3): 255-265.

Schultz,P.W., Gouveia, V.V, Cameron, L.D., Tankha, G.G., Schmuch, P.P. and Franek, M.M. (2005). Values and their relationship to environmental concern and conservation behaviour. Journal of Cross Cultural Psychology, 36(4):457-475. 
Schultz, P. W., Shriver, C., Tabanic, J.J. \& Khazian, A. M. (2004). Implicit connections with nature. Journal of Environmental Psychology 24, 31-42.

Schroeder, H. W. 2007 Place experience, gestalt and the human-nature relationship. Journal of Environmental Psychology 27, 293-309.

Sofield, T.H.B. and Li, F.M.S. (2007). China, ecotourism and cultural tourism: Harmony or dissonance? In H. James (Ed.), Critical issues in ecotourism: confronting the challenges. (pp. 368-385). London: Elsevier,

Sparks. B. (2007). Planning a wine tourism vacation? Factors that help to predict tourist behavioural intentions. Tourism Management. 28 (5),1180-1192.

Stern P. C. (2000) Toward a coherent theory of environmentally significant behaviour. Journal of Social Issues, 56(3), 407-427.

Stern, P. C. and Dietz, T. (1994). The value basis of environmental concern. Journal of Social Issues, 50(3), 407-424.

Stern, P. C., Dietz, T., Abel, T., Guagnano, G. A.,\& Kalof, L. (1999). A value-belief-norm theory of support for social movements: The case of environmental concern. Human Ecology Review, 6, 81-97.

Swarbrooke, J. (1999). Sustainable tourism management. Wallingford, CABI Publishing.

Thøgersen, J. and Olander, F. (2002). Human values and the emergence of a sustainable consumption pattern: A panel study. Journal of Economics Psychology. 23, 605-630.

Thompson, N. (2005). Inter-institutional relations in the governance of England's national parks: a governmentality perspective, Journal of Rural Studies, 21(3), 323-334.

Thompson, S. C. G. and Barton, M.A. (1994). Ecocentric and anthropocentric attitudes toward the environment. Journal of Environmental Psychology, 14(1), 149-157.

Wang, L. Chen, A. \& Gao, Z. (2011). An exploration into a diversified world of national park systems: China’s prospects within a global context. Journal of Geographic Sciences, 21(5), 882-896.

Wapner, P. \& Matthew, A. (2009). The humanity of global environmental ethics. The journal of environment and development. 18(2), 203-222.

Wearing, S and Neil, J. (2009). Ecotourism: impacts, potentials and possibilities. $2^{\text {nd }}$ ed. Oxford: ButterworthHeinemann.

Wen, Y. and Ximing, X. (2008). The differences in ecotourism between China and the West. Current Issues in Tourism. 11(6), 567-586.

Werner, O. \& Campbell, D. T. (1973). Translating, working through interpreters, the problem of decentering, In R. Naroll, \& R. Cohen, (Eds), A Handbook of Method in Cultural Anthropology (pp. 398-410). Columbia University Press. New York.

Westland, J.C. (2010). Lower bounds on sample size in structural equation modelling. Electronic Commerce Research and Applications, 9 (6), 476-487.

Wheeler, S. M. (2012). Climate change and social ecology. A new perspective on the climate change. London: Routledge.

Winter, C. (2007). The Intrinsic, instrumental and spiritual values of natural area visitor, Journal of sustainable tourism, 15(6), 599-616. 
World Database on Protected Areas. (2013). World Database on Protected Areas incorporating the UN List of Protected Areas. Available from: http://www.wdpa.org/ . [Accessed 18 April 2013].

Wurzinger, S. and Johansson M. (2006). Environmental concern and knowledge of ecotourism among three groups of Swedish tourists. Journal of Travel Research, 45, 217-226.

Yeoman, J. (2000). Achieving sustainable tourism: a paradigmatic perspective. In: M. Robinson, J. Swarbrooke, N. Evans, P. Long, \& R. Sharpley, (Eds.). Reflections on international tourism: Environmental management and pathways to sustainable tourism. (pp. 311-27). Sunderland: Business Education Publishers. 